THURSDAY, MARCH I6, IgIr.

\section{THE KAISER-WILHELM SOCIETY FOR THE PROMOTION OF SCIENCE.}

GERMANY, and its head, the Emperor, have again shown the world their gratitude for the achievements of science; if desired; the word gratitude may be interpreted in the sense of "favours to come." Not content with endowing the universities and technical high schools from the Exchequer with what appear to us relatively enormous sums, a society has been founded, under the:"protection" of the Emperor, for the advancement of science. It is instructive to note the difference between their-method and ours. Both countries possess what is called "technical education"; but while we' have founded schools in considerable number, destined to capture the workmen (who seldom attend) and the prospective foremen, they have aimed at the education of the manufacturers and the works managers. Instead of numerous institutions giving elementary science instruction, they have a few, imparting the most advanced. Instead of a system of small scholarships, intended to bribe the clever children of the lower middle class, they leave it to the parents to find out that their children, suitably trained, are equipped for their lifework, and will, if they are diligent, be certain of reasonable incomes, and respectable positions.

In this latest enterprise, too, the Germans have appealed, not to the moderately well-off, but to the rich. Membership of the new society may be acquired by private persons, or by firms, on the condition of an initial contribution of 20,000 marks ( $1000 l$.), payment of which, by special resolution of the Senate, may be distributed over several years, and besides this, an annual contribution of rooo marks a year, commutable by a lump sum of 40,000 marks, or $2000 \mathrm{l}$. The members are to be elected by the Senate, a body chosen by themselves at a general meeting, which must be held once each year, in February, but may be summoned also at any time by the president, or by any two members. Members of the Senate, consisting of at least ten members chosen by the contributors, hold office for five years; to it belong other members, not necessarily donors but Gelehrte, i.e. savants, or other persons who may be deemed useful, nominated directly by the Protector, that is, by the German Emperor. The election of members by the Senate requires the Protector's confirmation before it becomes absolute. Rules exist for the resignation of members and for the removal of defaulting members. The Senate meets twice a year, and holds a statutory meeting in March; it may also be summoned at other times by the Protector, by its Executive Committee, or by request from a third of its members. It elects a president, two vice-presidents, two treasurers, and two secretaries; the election of the three first also requires confirmation by the Protector. These form the executive committee of the society.

The object of the society is designated in its title, and in its first statute; it is "to promote the sciences, especially by the foundation and support of scientific institutes of research."

$$
\text { NO. } 2 \text { I 59, vOL. 86] }
$$

Readers of NATURE will have already read a translation of the address delivered at the opening of the society in presence of its Protector, by Prof. Emil Fischer, of Berlin, printed in the issue for February 23. The daily papers have informed us that at the celebration of the centenary of the Berlin University held last October the Emperor announced that this society had at its disposal a capital of half a million sterling. It is proposed to devote its income to the equipment of institutes in which men already eminent in their respective subjects will be installed. They will have the right to take student-assistants, i.e. young men, who wish to graduate in one or other of the universities; they will thus be able to pursue research, aided as much or as little as they please. Such a position was held, as member of the Berlin Academy, by Prof. van't Hoff, whose recent removal by death the whole scientific world deplores. $\mathrm{He}$ had a free hand, was not obliged to give any formal lectures, or to take part in the active management of the University, but was allowed, with the help of students, to work out his own problems in his own way, and his work on Stassfurth salts has been of great technical value. His words to the writer were, many years ago, that he thought it right to help his adopted country to solve its commercial problems, and that he had attempted to do so. But it must be understood that no such expectation is necessarily entertained of the incumbents of chairs at the proposed institutes; the progress of science, not necessarily of its industrial application, is contemplated. Our neighbours have learned the lesson that science, like virtue; brings its own reward.

It is wonderful how deeply the spirit of trust in science has penetrated the whole German nation. When Prof. Ostwald, many years ago, appealed to the Saxon Government for money to build his physicochemical laboratory, the Socialists in the Saxon Parliament voted for the grant to a man, believing that greater expenditure on pure science would contribute to greater industrial opportunities. This spirit, which permeates the German people, from the Emperor on his throne to the representatives of the peasants, causes admiration; would that it could inspire imitation!

One is led to speculate on the cause of this. Why is it that the people of Germany have such sympathy for scientific endeavour? The reasons are many.

First, and above all, is the discipline which the German people have undergone by their military training; more are thus prepared for practical life in a measure which cannot be otherwise attained. It has its disadvantages; on the whole, the people are not so self-reliant, but they become more trustworthy machines. Second, there is a deeper understanding of scientific achievements and their bearing on industry. This manifests itself in many ways; the German Government is not above asking for, and acting on, scientific advice. The social position of the savants, scientific and literary, is therefore assured, and the incomes of the higher posts compare favourably with those earned by professional men and manufacturers. This higher social standing secures attention to those who tender advice. Third, there is a constant ex- 
change between academic and industrial posts; many men leave chairs to become managers of factories; many men enter the teaching and investigating profession from factories. Chemical and physical factories, too, there form a training school for the younger scientific experts; where many are employed, the more advanced communicate their knowledge and the results of their experience to the junior members of the scientific staff; in fact, they have apprenticeship at its best. Here, in prosperous times, the manufacturer thinks that he has no need of scientific assistance; in times of bad trade he believes that he cannot afford it. And, lastly, the process of training the people has gone on in Germany for nearly a hundred years. Rewards have been given, not to successful examiners, and not in the form of scholarships; but have been earned in the battle of life, for which ample preparation has been given.

This spirit of trust in science has permeated to the highest in the land; that it has been fertile in practical results is amply proved by the inception of the KaiserWilhelm Society for the furtherance of science.

\section{MIMICRY IN THE BUTTERFLIES OF}

$$
\text { AFRICA. }
$$

African Mimetic Butterflies; being Descriptions and Illustrations of the principal known instances of Mimetic Resemblance in the Rhopalocera of the Ethiopian Region, together with an Explanation of the Millerian and Batesian Theories of Mimicry, and some account of the Evidences on which these Theories are based. By H. Eltringham. Pp. $136+$ $\mathrm{x}$ plates and map. (Oxford : Clarendon Press, Igro.) Price 5os. net.

THIS valuable work is in chief part devoted to the "Descriptions of Mimetic Associations in African Rhopalocera," illustrated by nine beautiful coloured plates (ii-x) and by a most useful map of Africa. This-the main object of the book-is preceded by an excellent introductory account of the structure and classification of butterflies, and of mimicry and its relationship to other uses of form, colour, and pattern. The introduction is illustrated by the admirable first plate, showing the characters of the fore-feet of the principal butterfly groups. The discussion of special objections to the theories of mimicry, and a consideration of the evidence by which they are supported, are wisely left to the concluding pages of the text. A useful bibliographical list and an excellent index complete the work.

The extraordinarily rapid growth of knowledge on this subject at the present day is seen in the fact that important new light has been already thrown on certain conclusions in the few months that have elapsed since the appearance of the volume. Thus on p. $3 I$ we read of the family raised by Mr. St. Aubyn Rogers from a female Hypolimnas misippus somewhat intermediate between the type and the form inaria, and of how the females, without exception, turned out to be inaria. But since the day of publication Mr. Rogers has bred in the same locality, Rabai, near Mombasa, another family from an inaria female parent, and in this instance all the female offspring were misippus! It should be mentioned in connection NO. 2 I 59, VOL. 86] with this hitherto unpublished result that misippus and inaria females are about equally common in the locality where the families were reared.

Again, when the book was published it was safe to assert (on p. 96) that the planemoides female form of Papilio dardanus is restricted to the areas where its Planema models are abundant; but Mr. Rogers has now sent an example of it from the neighbourhood of Rabai, and Mr. G. F. Leigh an evidently closely allied very rare form from Durban, the former much to the east, the latter immensely to the south of any locality from which the models have been recorded.

Then the comparatively few African examples of mimicry within the Nymphalinæ have been increased by the recent observations of $\mathrm{Mr}$. W. A. Lamborn that Diestogyna gambiae, the female of which resembles the abundant Catuna angustata, is constantly to be found in the company of this species.

Our knowledge of mimicry in Africa is progressing at a very rapid rate. To name only the principal naturalists who are directing their attention to this subject at the present moment, we have Mr. A. D. Millar and Mr. G. F. Leigh in Natal, Mr. C. F. M. Swynnerton in south-east Rhodesia, Mr. St. Aubyn Rogers in the Mombasa district, Mr. C. A. Wiggins at Entebbe, and Mr. W. A. Lamborn in the Lagos district. The present writer has found it most inspiring to be associated with all these keen observers and to receive many times in each year the tidings of new discoveries and the material on which they were based.

Mr. Eltringham's work will be of the utmost assistance to these and other naturalists, and it is to be hoped that it will be available in every African centre accessible to students of nature.

It will also be clear from the brief account of the plan and contents of the work that it is certain to be quite as valuable and efficient in stimulating and guiding the beginner as in aiding the expert in the search for fresh discoveries.

A careful and critical study has revealed comparatively few mistakes. All that have been detected are mentioned below, and in a book so full of statements of fact, the list must be regarded as a short one.

In mentioning Cethosia (p. 39, n. 2), the Oriental mimic of Danaida, it would have been well to point out that we here meet with one of the very rare instances of mimicry in the male, but not in the female. The mimicry is confined to the upper surface, and can hardly be looked upon as "remarkably accurate" in any species of this genus.

The male of Planema macarista should have been mentioned on p. 45 as a model of the aurivillii form of female of Acraea alciope. In both shape of wings and pattern the resemblance to this Planema is closer than to $P$. poggei, the model given by the authora conclusion very clearly expressed in the arrangement of plate viii., but inadvertently omitted from the text.

In discussing, on p. 52 , the scanty and somewhat imperfect mimicry of the abundant Danaine, Tirumala petiverana, the author omits the important consideration that the species is a recent intruder from another area-an intruder still retaining a close resemblance to its nearest Oriental allies. 